\section{Galería}

Fotográfica

REV EXP MED

2020;6(2).

Abril - Junio

\title{
Célula LE y nucleofagocito
}

\section{LE cell and nucleophyte}

\author{
César A. Cabrejos-Montalvo ${ }^{1, a}$, Katherine E. Ipanaqué-Muñoz ${ }^{1, a}$
}

El conocimiento de la célula LE puede considerarse que se inicia hace medio siglo, en 1948, cuando Hargraves et al, la descubren en un frotis celular de la médula ósea de una enferma con lupus eritematoso sistémico (LES). Su presencia es el resultado de la existencia de Anticuerpos Anti-nucleares en el suero del enfermo, específicamente anti-ADN histonas, dirigidos contra el núcleo alterado o roto de un linfocito, conjuntamente con la fijación de complemento. Con la coloración Wright o giemsa este núcleo alterado adquiere un aspecto homogéneo, se elimina de la célula y es fagocitado por el leucocito polimorfonuclear (PMN), con la consiguiente formación de un gran cuerpo de inclusión en su interior. Este es redondeado y voluminoso, su coloración es basofila, homogénea y carece de estructura cromatínica, con una reacción citoquimica propia del ADN despolimerizado. El núcleo del leucocito PMN queda rechazado hacia la periferie. En caso de no producirse fagocitosis, puede encontrarse aislado en los tejidos (cuerpos hematoxilinicos), o bien rodeado por un grupo de PMN (rosetas de PMN). Todos estos fenómenos son equivalentes (Célula LE., Cuerpos hematoxilinicos y rosetas) ${ }^{(1,2)}$.

La célula Tart o nucleofagocito es un macrófago que ha ingerido el núcleo y membrana celular intacta de otro polimorfonuclear. Los lóbulos del fagocitico suelen encontrarse en la periferia de la célula (3).

La técnica de diagnóstico que se utiliza para la observación de estas células se llama Técnica de las 2 horas: donde la sangre es extraída y desfibrinada con perlas de vidrio, y se coloca en incubación a $37^{\circ} \mathrm{C}$, durante 2 horas, luego se realiza el frotis sanguíneo, y finalmente se colorea con la tinción Wright o giemsa (4).

\footnotetext{
1. Laboratorio de Bioquímica, Universidad Nacional Pedro Ruiz Gallo. Lambayeque. Perú

a. Magíster en Microbiología
} 

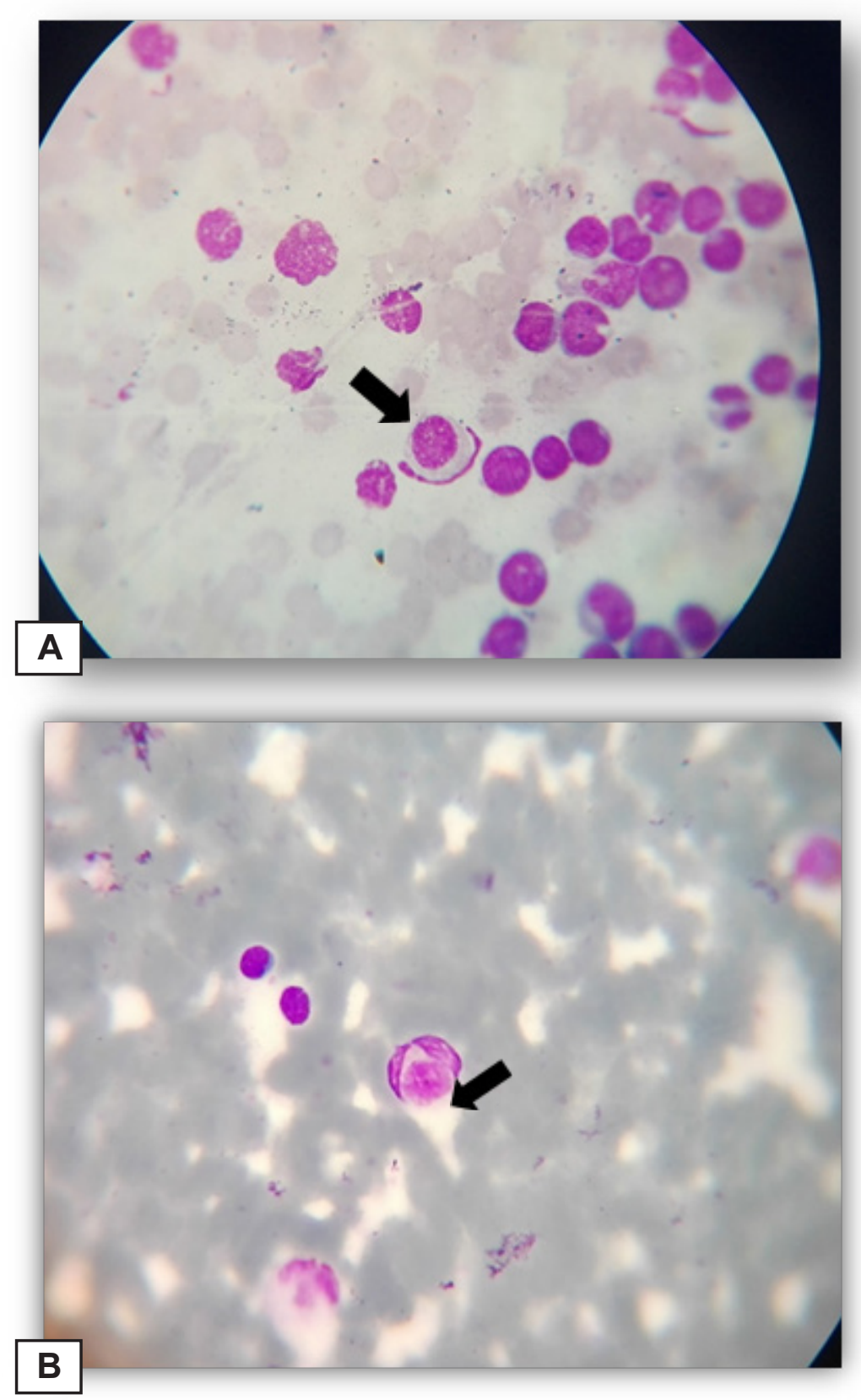

Figura 1. Nucleofagocito y Célula LE en frotis sanguíneo, coloreado con tinción Wright. A) Muestra tomada de médula: Nucleofagocito: Macrófago que ha fagocitado a otro leucocito intacto (1000 aumentos); B) Muestra tomada de sangre venosa: Célula LE: Neutrófilo que ha fagocitado núcleo alterado de otro leucocito (1000 aumentos).

Fuentes de financiamiento: Autofinanciado

\section{REFERENCIAS BIBLIOGRÁFICAS}

1. Cabrejos M; Ipanaque M; Espinoza V; Determinación del Fenómeno L.E (Lupus Eritematoso) por efecto del (Byocoril) en Cavia porcellus (cobayo). Rev. Rebiolest 2013; 1(2): e23

2.- Carrillo R; Carrillo J; Rosillo J; Giron V; Fenomeno de las cèlulas de lupus eritematoso (LE): reporte de un caso. Rev. Invest Med Sur Mex 2012; 19(3): 190-192.

3.- Rivero M; Ledda A; Segura V; Rol de Laboratorio Inmunológico en el estudio de pacientes con derrame pleural. Rev. Medica Universitaria 2013; 9(1).

4.- Manascero A; Atlas de hematología. $1^{\text {a }}$ ed. Editorial Pontifica Universidad Javeriana. Bogotá. 2014. 